\title{
Hydrologic controls on DOC, As and Pb export from a polluted peatland - the importance of heavy rain events, antecedent moisture conditions and hydrological connectivity
}

\author{
T. Broder and H. Biester \\ Institut für Geoökologie, AG Umweltgeochemie, Technische Universität Braunschweig, Langer Kamp 19c, \\ 38106 Braunschweig, Germany \\ Correspondence to: T. Broder (t.broder@tu-bs.de)
}

Received: 23 February 2015 - Published in Biogeosciences Discuss.: 30 March 2015

Accepted: 18 July 2015 - Published: 6 August 2015

\begin{abstract}
Bogs can store large amounts of lead $(\mathrm{Pb})$ and arsenic (As) from atmospheric deposition of anthropogenic emissions. $\mathrm{Pb}$ and $\mathrm{As}$ are exported along with dissolved organic carbon (DOC) from these organic-rich systems, but it is not yet clear which hydrological (pre)conditions favor their export. This study combines a 1-year monitoring of precipitation, bog water level and pore water concentration changes with bog discharge and DOC, iron, $\mathrm{As}$ and $\mathrm{Pb}$ stream concentrations. From these data, annual DOC, $\mathrm{As}$, and $\mathrm{Pb}$ exports were calculated. Concentrations ranged from 5 to $30 \mathrm{mg} \mathrm{L}^{-1}$ for DOC, 0.2 to $1.9 \mu \mathrm{g} \mathrm{L}^{-1}$ for As, and 1.3 to $12 \mu \mathrm{g} \mathrm{L}^{-1}$ for $\mathrm{Pb}$, with highest concentrations in late summer. $\mathrm{As}$ and $\mathrm{Pb}$ concentrations significantly correlated with DOC concentrations. Fluxes depended strongly on discharge, as $40 \%$ of As and $43 \%$ of $\mathrm{Pb}$ were exported during $10 \%$ of the time with the highest discharge, pointing out the over-proportional contribution of short-time, high-discharge events to annual As, $\mathrm{Pb}$ and $\mathrm{DOC}$ export. Exponential increase in element export from the bog is explained by connection of additional $\mathrm{DOC}$, $\mathrm{As}$ and $\mathrm{Pb}$ pools in the acrotelm during water table rise, which is most pronounced after drought. $\mathrm{Pb}$, As and DOC concentrations in pore water provide evidence of an increase in the soluble $\mathrm{Pb}$ pool as soon as the peat layer becomes hydrologically connected, while DOC and As peak concentrations in runoff lag behind in comparison to $\mathrm{Pb}$. Our data indicate a distinct bog-specific discharge threshold of $8 \mathrm{~L} \mathrm{~s}^{-1}$, which is thought to depend mainly on the bogs size and drainage conditions. Above this threshold, element concentrations do not further increase and discharge becomes diluted. Combining pore water and discharge data shows that $\mathrm{As}$ and $\mathrm{Pb}$ exports are dependent on not only the amount
\end{abstract}

of precipitation and discharge but also on the frequency and depth of water table fluctuations. Comparing the annual bog $\mathrm{As}$ and $\mathrm{Pb}$ export with element inventories indicates that $\mathrm{As}$ is much more mobilized than $\mathrm{Pb}$, with annual fluxes accounting for 0.85 and $0.27 \%$ of total $\mathrm{As}$ and $\mathrm{Pb}$ inventory, respectively.

\section{Introduction}

Peatlands provide important services in the environmental system. They play an important role in the storage of carbon and other elements such as heavy metals. On the one hand, the filtering function of peatlands partly prevents the input of these pollutants to streams. On the other hand, peatlands can release heavy metals as soluble DOM-metal complexes. However, as they act as a major carbon sink, peatlands are also the greatest source of dissolved organic carbon (DOC) to the aquatic system (Aitkenhead et al., 1999). Several studies demonstrated runoff, water level fluctuations and temperature to be the most important controls on terrestrial DOC production and export (Freeman et al., 2001; Hongve et al., 2004; Köhler et al., 2008; Seibert et al., 2009; Laudon et al., 2011). Recently, numerous studies describe the emerging problem of rising DOC levels in streams and lakes especially in catchment areas comprising peatlands (e.g., Worrall et al., 2004; Monteith et al., 2007), which might cause severe problems for aquatic biota and in drinking water production (Chow et al., 2003). Besides the observed general increase in concentrations, which has been attributed to the 
decrease in acid rain deposition or temperature rise (Freeman et al., 2001; Evans et al., 2005; Monteith et al., 2007), a flushing effect, which produces high instantaneous DOC loads during high-discharge events after a summer dry period, has been described (e.g., Worrall et al., 2002; Clark et al., 2007). Even though temporally limited, the high concentrations might affect the aquatic system even stronger. This effect gains more importance through the predicted climate change with enhanced dry periods and more frequent heavy rain events (IPCC, 2013). How these high DOC concentrations built up after re-wetting of the peatland's near-surface layer is not yet fully understood. Fenner and Freeman (2011) proposed that the microbial DOC production is stimulated after a drought period by reduced concentrations of phenolic compounds through an enhanced phenol oxidase activity. Moreover, release of DOC adsorbed to iron (oxy)hydroxides through iron (oxy)hydroxide dissolution after re-wetting and decreasing redox potential has been shown to be an important process for DOC dynamics in peatlands (Bauer and Blodau, 2009; Knorr, 2013; Riedel et al., 2013), as well as DOC solubilization through pH rise (Grybos et al., 2009). Similarly, Clark et al. (2012) described a decrease in DOC solubility due to acidification during droughts.

Although the general focus in most studies is on changing DOC dynamics, it is also known that some elements are mainly exported by transport with DOC to the discharging stream. Lead $(\mathrm{Pb})$ strongly binds to organic matter (Tipping, 1998; Rothwell et al., 2007), and high DOC concentrations increase $\mathrm{Pb}$ mobility (Jordan et al., 1997). In spite of the high affinity of arsenic (As) to iron (oxy)hydroxides, recent mechanistic studies have revealed a strong binding of As to sulfhydryl groups of organic matter in the anaerobic peat layer (Langner et al., 2011, 2014). Due to the low pH $(<4.5 \mathrm{pH})$ and the low amount of mineral phases in peat, a correlation of DOC and As concentrations in bog-draining streams has been observed (Rothwell et al., 2009; Neubauer et al., 2013). Moreover, As is known to be subjected to postdepositional mobilization due to water level fluctuations and resulting redox changes (Blodau et al., 2008; Rothwell et al., 2009; Langner et al., 2014).

Bogs, which receive element inputs exclusively by atmospheric deposition, as well as other peatland types have the potential of accumulating $\mathrm{As}$ and $\mathrm{Pb}$ in the peat. The anthropogenic deposition rate of those two elements largely exceeds preindustrial background fluxes (Shotyk, 1998; Bindler, 2006). Mining activity and fossil fuel combustion, especially emissions from burning of leaded gasoline, often resulted in high $\mathrm{As}$ and $\mathrm{Pb}$ concentrations in peat layers which developed over the past centuries. Based on observed metal concentrations, some peatlands, especially those influenced by mining areas, would even have to be classified as highly contaminated soils.

The near-surface layer of a bog, the acrotelm, is the most active part, and drives most of the bog's discharge (Evans et al., 1999; Holden and Burt, 2003) and DOC production
(Clark et al., 2008). Due to high porosity, the acrotelm has a high hydraulic conductivity and is characterized by recurrent water table drawdowns and aeration resulting in higher biological activity. Moreover, this near-surface peat layer, which often hosts large amounts of atmospherically derived metals, is the main source of metal release from ombrotrophic peatlands.

Up to now, most studies on heavy metal release from contaminated peatlands have only focused on discharge. Studies connecting DOC export with in situ pore water chemistry measurements are rare or lacking with regard to $\mathrm{Pb}$ and As. Clark et al. (2005) found a strong correlation between peat soil solution DOC and stream water DOC concentrations over a 10-year record. Many field or laboratory studies have focused on DOC production in view of water level, redox state, acidification, temperature or microbial conditions (e.g., Grybos et al., 2009; Clark et al., 2012; Evans et al., 2012) without a connection to discharge measurements or have been conducted in mineral soil environments (e.g., Kokfelt et al., 2009; Singh et al., 2014; for Pb, see Vinogradoff et al., 2005). With regard to As, Blodau et al. (2008) found a higher release of As in minerogenic peat mesocosms after a drought period, which is in line with leaching experiments described by Tipping et al. (2003). Rothwell et al. (2009) observed higher As concentrations during late summer storm flow after the summer dry period in a bog catchment.

The aim of this study is to gain further understanding in the generation and controls of $\mathrm{Pb}$ and $\mathrm{As}$ export from ombrotrophic peatlands. If the export of $\mathrm{Pb}$ and $\mathrm{As}$ is mainly controlled by DOC production and transport, higher metal concentrations and fluxes are expected during periods of elevated DOC concentrations. Moreover, export dynamics should strongly depend on peatland hydrology. This study tries to unravel the importance of hydrologic conditions such as antecedent bog water levels, as well as precipitation, temperature and $\mathrm{pH}$ for the export of $\mathrm{As}$ and $\mathrm{Pb}$. We expect that these factors mainly control hydrologic pathways, DOC production and the hydraulic connection of different $\mathrm{As}$ and $\mathrm{Pb}$ pools. We thus aim to investigate to which extent $\mathrm{As}$ and $\mathrm{Pb}$ export is constrained by supply of DOC and related soluble metal organic complexes or discharge quantities.

To tackle these questions we chose a bog which is heavily contaminated by $\mathrm{As}$ and $\mathrm{Pb}$ through historic mining activities and is known to exhibit high $\mathrm{As}$ and $\mathrm{Pb}$ concentrations in the acrotelm. We continuously monitored direct bog discharge at a first-order stream to gain information of the DOC, $\mathrm{Pb}$ and As export dynamics dependent on precipitation. To combine discharge generation and element concentrations with (pre)conditions within the peat catchment, we sampled pore water to investigate time- and depth-resolved DOC and metal release patterns and monitored temperature, precipitation and water level at the bog. For an estimation of the overall export and mobilization potential from the bog, we calculated fluxes and peat $\mathrm{As}$ and $\mathrm{Pb}$ inventories. To examine the importance of storm-flow events, we conducted high-resolution 
measurements occasionally during snowmelt and rain events in spring and fall.

\section{Materials and methods}

\subsection{Study area}

The Odersprung bog (OS; $52^{\circ} 46.383^{\prime} \mathrm{N}, 10^{\circ} 33.816^{\prime} \mathrm{E}$; $800 \mathrm{~m}$ a.s.l., $1500 \mathrm{~mm}$ mean annual precipitation and $5^{\circ} \mathrm{C}$ mean annual temperature) is an ombrotrophic peatland located within the nature protection area in the Harz Mountains in northwestern Germany. The treeless part of the bog covers an area of about 17 ha and has a mean peat depth of $3 \mathrm{~m}$ (Beug et al., 1999). Vegetation is dominated by Sphagnum magellanicum and Sphagnum rubellum. Eriophorum angustifolium and Molina caerulea occur less frequently (Baumann, 2009). The bog is drained by a small erosion rill which originates within the bog. Discharge sampling was conducted at the rill outflow of the bog where all water is exclusively received from the bog. Previous studies on the effect of past local mining activities in the Harz Mountains reported $\mathrm{Pb}$ and As peat concentrations of up to 2300 and $100 \mathrm{mg} \mathrm{kg}^{-1}$, respectively, which is higher than background values by a factor of $10000(\mathrm{~Pb})$ (Biester et al., 2012).

\subsection{Sampling and field measurements}

Seasonal discharge sampling was conducted from April to November 2013 covering the time from snowmelt to the beginning of snowfall. Water samples were taken in a 6-day interval by an automated water sampler (ISCO autosampler 3700), equipped with $0.5 \mathrm{~L} \mathrm{PE}$ bottles and a Teflon hose, which was automatically rinsed with sample water prior to each sampling. Further grab samples as well as $\mathrm{pH}$ and electric conductivity measurements were conducted every 2 to 3 weeks. For grab samples, new $50 \mathrm{~mL}$ PE tubes were used and previously rinsed with sample twice before sampling. For all sampling techniques, blank controls were run. Several stormflow events were sampled at high frequency (every $3 \mathrm{~h}$ ) over a period of 3 days. At all sampled events the catchment was free of ice and snow.

Pore water samples at the Odersprung bog were taken using a suction sampler described in Broder et al. (2012). In short, the sampler consisted of PE-sinter slides $(5 \times 0.5 \times 1 \mathrm{~cm})$ inserted in a $3.5 \mathrm{~m}$ long rod. Slides were connected by tubing to a stopcock above the peatland surface. Samples were taken by means of PE syringes and transferred to new PE tubes which had previously been rinsed with sample. Sampling resolution was 20 to $60 \mathrm{~cm}$ depth and 30 to $210 \mathrm{~cm}$ depth. The suction sampler was installed within the catchment area of the erosion rill (Fig. 1). Close to the pore water sampler, a peat core was extracted using a Russian peat corer (Eijkelkamp Agrisearch Equipment). Cores were collected down to $300 \mathrm{~cm}$ depth, sliced into $2.5 \mathrm{~cm} \mathrm{sec}$ tions, frozen and freeze-dried. For the calculation of As and

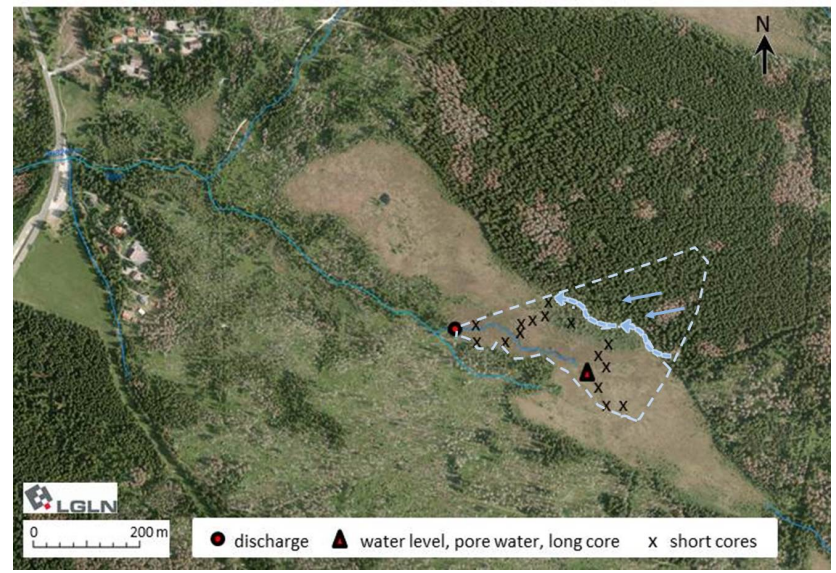

Figure 1. Location of the study area in the Harz Mountains, northwestern Germany, with catchment boundaries indicated by the dashed light-colored line. The circle denotes discharge monitoring site and the triangle marks location of pore water sampling, as well as water level monitoring and peat core retrieval. Crosses mark the location of short cores for inventory calculations. Map source: Lower Saxony Ministry for Environment, Energy and Climate Protection.

$\mathrm{Pb}$ inventories in the acrotelm, 15 short cores $(30 \mathrm{~cm}$ depth) were sampled by means of a Wardenaar peat profile sampler (Eijkelkamp Agrisearch Equipment).

Discharge at the bog outlet was quantified using a V-notch weir. Stage was recorded every $15 \mathrm{~min}$ by a water level logger (Odyssey Dataflow Systems) for the recalculation to the actual discharge. Water level at the bog site was monitored in close proximity to the pore water sampler using PVC piezometer tubes of $4 \mathrm{~cm}$ diameter, fully slotted until $120 \mathrm{~cm}$ depth, and a water level logger (Odyssey Dataflow Systems). Temperature, relative humidity and precipitation (using a tipping-bucket rain gauge) were monitored (Tinytag TGP-4500 and 4810, Gemini) at the site.

\subsection{Laboratory analyses}

Water samples were filtered with $0.45 \mu \mathrm{m}$ nylon filters (Merck, Millipore) within the laboratory and stored at $4{ }^{\circ} \mathrm{C}$. All water samples were analyzed for total dissolved organic carbon using a thermo-catalytic total carbon analyzer (Analytik Jena multi N/C 2100S) using the NPOC method. $\mathrm{As}, \mathrm{Fe}$ and $\mathrm{Pb}$ concentrations were determined by means of an ICP-MS (Agilent 7700). Instrumental drift and quality was checked by certified reference materials (SPS-SW 1 and SLRS-4, riverine water, National Research Council, Canada). Detection limits for $\mathrm{Fe}, \mathrm{As}$ and $\mathrm{Pb}$ were $0.01,0.001$ and $0.001 \mu \mathrm{g} \mathrm{L}{ }^{-1}$, respectively.

All peat samples were freeze-dried, milled and further analyzed with a resolution of $2.5 \mathrm{~cm}$ to $50 \mathrm{~cm}$ depth and $10 \mathrm{~cm}$ resolution below. Peat $\mathrm{As}$ and $\mathrm{Pb}$ concentrations were determined with an energy-dispersive miniprobe multielement 
analyzer (EMMA-XRF; see Cheburkin and Shotyk, 1996). Carbon and nitrogen concentrations in peat were measured using an elemental analyzer (Euro EA 3000, HEKAtech).

\subsection{Flux calculations and $\mathrm{As}$ and $\mathrm{Pb}$ inventory estimates}

DOC, As and $\mathrm{Pb}$ annual fluxes were estimated by calculating the total annual load from analyzed water samples and the continuous discharge record using method 5 introduced by Walling and Webb (1985) and recommended by Littlewood (1992): :

Load $=K \times Q_{\mathrm{r}}\left(\frac{\sum_{i=1}^{n} C_{\mathrm{i}} Q_{\mathrm{i}}}{\sum_{i=1}^{n} Q_{\mathrm{i}}}\right)$,

where $K$ is a conversion factor (here number of seconds per year), $Q_{\mathrm{r}}$ is the annual mean discharge from the continuous record, $C_{\mathrm{i}}$ is the instantaneous concentration, $Q_{\mathrm{i}}$ is the instantaneous discharge and $n$ is the number of samples $(n=112)$. Load estimates were divided by catchment size to gain fluxes in $\mathrm{g} \mathrm{ha}^{-1} \mathrm{a}^{-1}$.

The rill catchment area is mainly covered by an open and treeless part of the bog ( 8 ha; see Fig. 1). Catchment boundaries were determined by topographic conditions and the occurrence of perennial streams, which required including a part of a hillslope with shallow podsolic forest soils. However, it was perceived that small pools build up between the domed bog and forested areas, which drain downslope during rain events, and do not discharge into the bog (see also Fig. 1). Therefore, the chemical characteristic from the bog stream should not be biased by forest soil draining water. Flux calculations from high-frequency concentration measurements during snowmelt and discharge events were calculated according to method 3 of Walling and Webb (1985), where instantaneous loads were calculated by the measured concentration and the integrated discharge data of the preceding sampling interval $(3 \mathrm{~h})$ to obtain a robust discharge estimate. To further improve flux estimates the annual record was separated either by season or by hydrograph and was additionally calculated by method 2 of Walling and Webb (1985). Standard error and $95 \%$ confidence limits of flux calculations were conducted after Hope et al. (1997). As and Pb inventories for the peatland catchment were calculated from the median value of the upper $30 \mathrm{~cm}$ As and $\mathrm{Pb}$ inventories of all 16 peat cores to estimate an inventory per unit area of the bog surface. Uncertainties in the inventory calculations were estimated by the standard deviation from the mean of all As and $\mathrm{Pb}$ inventories of the 16 peat cores.

\section{Results and discussion}

\subsection{Hydrologic conditions}

The year 2013 was characterized by strong snow melt and several intense rain events (Fig. 2). The precipitation record before day of the year (DOY) 100 (middle of April) and after DOY 289 (end of October) was affected by snowfall, which produces exceptionally high precipitation values that distort quantification as we used a tipping bucket. On two other occasions the rain gauge became clogged; thus no rainfall was recorded for a few high-flow discharges and water level rises (DOY 150-162 and DOY 256-270). During the snowfree record from mid-April to mid-October the catchment received $537 \mathrm{~mm}$ rain. Monthly precipitation totals recorded highest rainfall in fall, while a longer dry period prevailed in summer.

In total, 36 discharge events with high flow could be distinguished after the end of snowmelt. High-flow events partly followed shortly after a preceding event, especially in fall, when rain was frequent. The two main discharge events of the 2013 record triggered by a longer rainfall period occurred in spring and peaked at a discharge of 44 and $55 \mathrm{~L} \mathrm{~s}^{-1}$. The three largest events in fall peaked at $23-24.5 \mathrm{~L} \mathrm{~s}^{-1}$. High discharge values at the beginning of the record indicate that snowmelt contributed an important portion to the annual discharge (Fig. 2). As a quantification of the complete snowmelt discharge was impossible, calculated annual element fluxes might be underestimated (Dyson et al., 2011). A typical event hydrograph exhibits a steep rising and falling limb with a slow decline as the event subsides. With a low-flow limit set at $0.3 \mathrm{~L} \mathrm{~s}^{-1}$ by thorough visual hydrograph separation, low flow occurred over more than $28 \%$ of the time record but contributed only $2.5 \%$ of total discharge. This is indicative of an event runoff regime with negligible groundwater contribution. In fact, constant base flow over longer periods could never be observed, as flow steadily declined without rainfall until it almost ceased when the accessible water pool in the acrotelm was depleted. Therefore, we do not refer to base flow conditions but rather use the term low flow as no steady groundwater component seems to contribute to the bog's discharge. The flashy hydrograph response fits with rapid runoff generation by near-surface and surface flow. The dominance of this kind of runoff generation is similar to previously reported flashy regimes at blanket bogs (Evans et al., 1999; Holden and Burt, 2003).

Lag times from the beginning of rainfall to discharge were short, with a mean response time of $1.3 \mathrm{~h} \pm 0.5 \mathrm{~h}$. Shortest lag times occurred when discharge was still high at the beginning of a new high-flow event similar as has been observed for a blanket bog (Daniels et al., 2008). This instantaneous response indicates that, with wet preconditions, surface runoff prevails as this is the most rapid runoff component.

Despite high rainfall events in summer, only small corresponding discharge events were recorded. Here, the wa- 

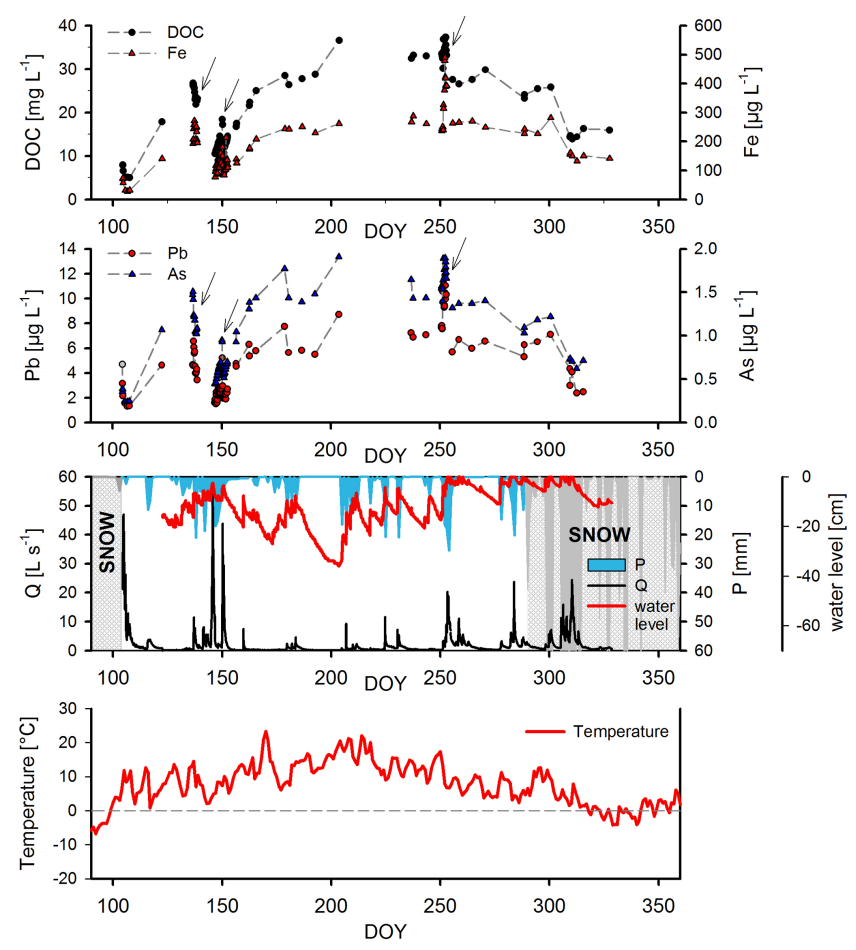

Figure 2. Annual concentration record of $\mathrm{DOC}, \mathrm{Fe}, \mathrm{Pb}$ and $\mathrm{As}$ (top and upper middle panels) at the bog outlet. Annual records of bog water level, daily precipitation, discharge and temperature (bottom and lower middle panels). Sampled discharge events are highlighted by black arrows. Note that winter precipitation as snow cannot be quantified.

ter pool of the bog's near-surface layer is recharged before discharge takes place. The process is clearly depicted in Fig. 2, where it can be seen that the water level rose almost immediately after beginning of rainfall at DOY 205. Over the entire record the water table ranged between 3.5 above and $36 \mathrm{~cm}$ below the peat surface, with a median depth of $10.5 \mathrm{~cm}$. The lowest water level occurred during the summer drought $(36 \mathrm{~cm}$ depth) after 20 days without precipitation. From the 36 discharge events, 22 could be classified as following wet and 13 as following dry preconditions based on the median water level of $10.5 \mathrm{~cm}$ as the threshold value. Estimated runoff-to-precipitation ratios for discharge events were lowest for those events with exceptionally dry preconditions following the summer drought. In general, dry precondition events exhibited lower runoff-to-precipitation ratios than wet precondition events.

\subsection{DOC, As and Pb stream concentrations}

DOC release patterns from the Odersprung bog were similar to those reported from other peatlands (e.g., Worrall et al., 2002; Laudon et al., 2004; Clark et al., 2008). Lowest DOC concentrations $\left(5 \mathrm{mg} \mathrm{L}^{-1}\right)$ were observed in the middle of April during snowmelt, when dilution was highest, whereas

highest DOC concentrations $\left(\sim 30 \mathrm{mg} \mathrm{L}^{-1}\right)$ occurred in late summer to fall, when DOC production was highest and mostly low-flow conditions occur (Fig. 2). DOC concentration decreased thereafter until the beginning of winter and the end of the annual record. This general seasonal trend with lower concentrations in winter and spring and increasing concentrations during summer can be attributed to reasons related not to discharge but rather to the seasonal temperature dynamics and therefore enhanced biological activity, organic matter decomposition and solubility. The low DOC concentrations during snowmelt can be attributed to not only a dilution effect but also to a smaller extent to the low DOC production and storage during winter (Dyson et al., 2011).

Concentrations of As ranged from 0.2 to $1.9 \mu \mathrm{gL}^{-1}$, whereas $\mathrm{Pb}$ concentrations were significantly higher (1.3 to $12 \mu \mathrm{g} \mathrm{L}^{-1}$ ) and in some cases even exceeded the WHO threshold value for drinking water $\left(10 \mu \mathrm{g} \mathrm{L}^{-1}\right.$; WHO, 2011). Highest $\mathrm{Pb}$ concentrations occurred during a rain event in fall, which is discussed further below. Concentrations of As showed the same seasonal trend as observed for DOC, with highest concentrations in summer (Fig. 2). This trend was recognizable for $\mathrm{Pb}$ as well, but less pronounced (Fig. 2). Concentrations of both $\mathrm{As}$ and $\mathrm{Pb}$ significantly correlated with DOC $\left(R^{2}: 0.96\right.$ and 0.87 , respectively), which supports the assumption that both elements are mainly transported along with DOC within and outside of this organic-rich system. $\mathrm{Pb}$ is known to strongly bind to organic matter (Tipping, 1998). As forms soluble DOM complexes (Buschmann et al., 2006) but also shows sorption to iron (hydr)oxides or formation of As-Fe-NOM colloids or complexes (Ritter et al., 2006; Thomas Arrigo et al., 2014). Accordingly, Fe concentrations significantly correlate with DOC and As (Fig. 2; $R^{2}$ Fe/DOC: $0.86 ; R^{2}$ Fe/As: 0.80$)$. At the bog's outflow, acidic conditions $(<\mathrm{pH} 4.5)$ prevail over the whole sampling period. Under these conditions, iron-DOM complexes such as a ternary complex of As-Fe-DOM dominate the soluble fraction (Tipping et al., 2002; Lofts et al., 2008; Neubauer et al., 2013). Exports of As, Fe, and DOC thus seem to be strongly linked, and it is likely that both elements are mobilized by the same processes and originate from the same source area within the bog.

\subsection{DOC, As and $\mathrm{Pb}$ concentrations during storm flows}

Three high-frequency samplings of storm flows were conducted at the bog outlet in 2013. The first spring event started after a longer low-flow period and a low water level within the bog of around $13 \mathrm{~cm}$ below surface, indicating dry preconditions (DOY 137, 18 May 2013; Fig. 3). The second event followed shortly after the first, but with wet preconditions (DOY 150, 31 May 2013). The third sampled stormflow event occurred in fall with again dry preconditions and a water level of around $12 \mathrm{~cm}$ below surface (DOY 251, 9 September 2013; Fig. 3). In general, concentration changes in all elements during high-discharge events were rather 

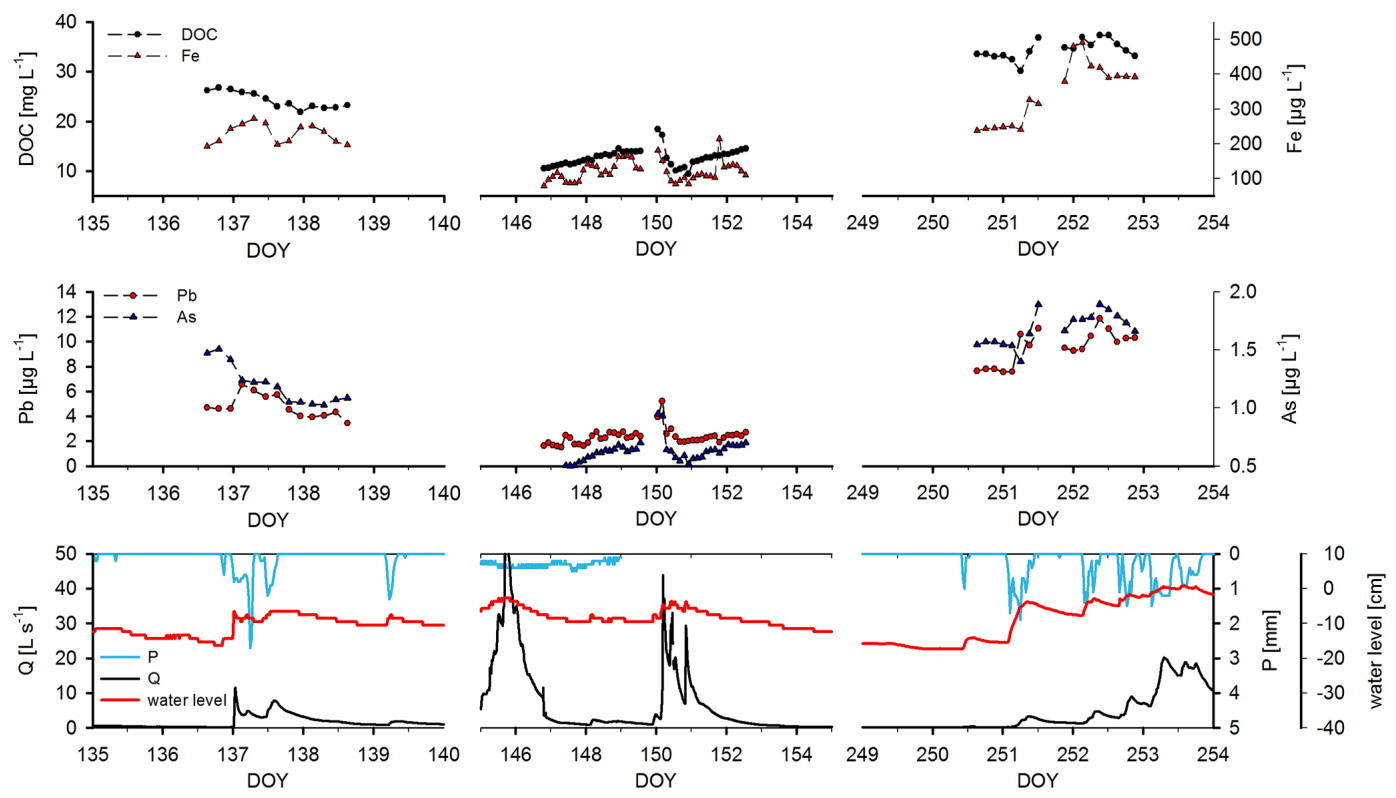

Figure 3. High-resolution DOC, As and Pb concentrations during recorded spring (DOY 135-155) and fall (DOY 250-260) events. Records of bog water level, precipitation (30 min resolution) and discharge (bottom).

small compared to the annual variations, indicating that high precipitation and increased runoff do not necessarily cause dilution but seem to mobilize or connect additional pools of $\mathrm{DOC}$, As and $\mathrm{Pb}$.

At the first event, DOC and As concentration started to decrease immediately after the onset of high flow from $26.8 \mathrm{mg} \mathrm{L}^{-1}$ and $1.5 \mu \mathrm{g} \mathrm{L}^{-1}$ to $21.8 \mathrm{mg} \mathrm{L}^{-1}$ and $1.0 \mu \mathrm{g} \mathrm{L}^{-1}$, respectively, at the end of the event. No flushing effect with increasing stream water concentrations was visible (Fig. 3). However, $\mathrm{Pb}$ concentrations immediately increased with rising water level and discharge. Water levels rose from 13 to $6 \mathrm{~cm}$ depth, while $\mathrm{Pb}$ concentrations increased from 5 to $7 \mu \mathrm{g} \mathrm{L}^{-1}$. With the falling limb of the hydrograph, $\mathrm{Pb}$ concentrations also decreased to concentrations of about $4 \mu \mathrm{g} \mathrm{L} \mathrm{L}^{-1}$. The reason for the different behavior of $\mathrm{Pb}$ compared to $\mathrm{As}$ and DOC is unknown. The increase in $\mathrm{Pb}$ concentrations with increasing water level indicates that there is no dilution but that additional $\mathrm{Pb}$ pools are mobilized as near-surface peat layers become hydrologically connected to discharge. It is still unknown how the $\mathrm{Pb}$ pool evolves during the winter months, but it is probably by mineralization of organic matter in the acrotelm. In the case of DOC concentrations, which did not increase with increasing water level, we assume that a potentially mobile DOC pool had not yet been built up in spring, when temperature and thus biological productivity were still low. The role of redox-induced formation or dissolution of mineral Fe phases for As mobilization during water level changes is not yet understood. One explanation could be that As and DOC, as well as As-organic complexes, are adsorbed to precipitated iron oxides when water levels are low. The re-establishment of anoxic conditions after water level rise causes a reductive dissolution of iron oxide and a release of DOC and As. However, these processes are assumedly too slow to be effective within a storm-flow event (Grybos et al., 2007). This hypothesis will be further discussed in the Sect. 3.5 further below.

The second storm-flow event exhibited low concentrations compared to the annual concentration record at this site, starting with concentrations of $13 \mathrm{mg} \mathrm{L}^{-1}$ DOC, $2 \mu \mathrm{g} \mathrm{L}-1$ $\mathrm{Pb}$ and $0.7 \mu \mathrm{g} \mathrm{L}^{-1}$ As when low-flow conditions had just re-established after a large rain event. During the low-flow regime, concentrations slightly increased until the onset of the high-discharge event. DOC and As concentrations peaked at $18 \mathrm{mg} \mathrm{L}^{-1}$ and $1 \mu \mathrm{g} \mathrm{L}^{-1}$, respectively, at the onset of the event, while $\mathrm{Pb}$ concentrations only peaked $3 \mathrm{~h}$ later, coinciding with maximum flow and a water level rise from 9.5 to $5.6 \mathrm{~cm}$ depth. Regardless of further smaller discharge peaks, $\mathrm{DOC}$, As and $\mathrm{Pb}$ stream concentrations decreased to former low-flow concentration levels until the end of the discharge event. Even though a distinct rise in concentrations of DOC, $\mathrm{As}$ and $\mathrm{Pb}$ caused by this rain event was evident, concentration ranges for all three elements were low and of the same magnitude as lower concentrations before the first event in May. This indicates a strong depletion of all three elements through the directly preceding event, which exhibited the highest recorded discharge of the whole record. The obvious exhaustion of potentially mobile DOC, As and $\mathrm{Pb}$ here, induces an element export constrained by production rates. As low flow established again after this rain event, concentrations started to slowly rise again as was observed under low flow just before the rain event. 
During the fall event, concentrations before the event were higher than in spring, with $33.5 \mathrm{mg} \mathrm{L}^{-1} \mathrm{DOC}, 8 \mu \mathrm{g} \mathrm{L}^{-1} \mathrm{~Pb}$ and $1.5 \mu \mathrm{g} \mathrm{L}^{-1}$ As. During this event, DOC, $\mathrm{Pb}$ and $\mathrm{As}$ behave differently (Fig. 3). DOC concentrations first decreased at the onset of the rising limb of the hydrograph and rising water level within the bog, but thereafter DOC concentrations started to rise until discharge peaked (Fig. 3) and remained high at 35 to $37 \mathrm{mg} \mathrm{L}^{-1}$ until discharge increased even further. Unfortunately, the automated sampler failed to sample a part of the following main event, but DOC concentrations after the event were again much lower $\left(27 \mathrm{mg} \mathrm{L}^{-1}\right.$, DOY 255) than concentrations before the whole event. The As concentration dynamics during this fall event followed those of DOC with a peak concentration of $1.9 \mu \mathrm{g} \mathrm{L}^{-1}$. For $\mathrm{Pb}$, the first decrease in concentration was not apparent, but an immediate rise to higher concentrations and a second discharge peak also resulted in distinctly higher $\mathrm{Pb}$ concentrations of up to $11.9 \mu \mathrm{g} \mathrm{L}^{-1}$. After the event $\mathrm{As}$ and $\mathrm{Pb}$ concentrations were slightly lower than before the event $\left(6 \mu \mathrm{g} \mathrm{L}{ }^{-1}\right.$ $\mathrm{Pb}$ and $1.2 \mu \mathrm{g} \mathrm{L}^{-1} \mathrm{As}$ ). In line with the different discharge peaks, the water level responded immediately to rainfall with a stepwise increase up to a level of $1 \mathrm{~cm}$ above the peat surface. DOC and As concentrations evidently peaked shortly after the discharge peak and even decreased with increasing discharge, which can be indicative of a fast runoff component with less intense DOC and As mobilization or dilution. However, $\mathrm{Pb}$ concentrations were not diluted but instead increased with the first discharge peak, which runs counter to the pattern observed for DOC and As. Similarly, Rothwell et al. (2007) also observed variable peak dynamics for $\mathrm{Pb}$ amongst other metals over several fall discharge events. To summarize the response of $\mathrm{Pb}$ stream water concentrations for all three rain events, $\mathrm{Pb}$ concentrations seem to respond immediately to water level rise within the bog with an increasing in concentrations. As fast surface runoff at the beginning of the event can be ruled out as a reason for the initial decrease in As and DOC stream concentrations, the different behavior of the three elements indicates that DOC and As seemed to be controlled by different mobilization processes than $\mathrm{Pb}$. Concentrations of $\mathrm{DOC}, \mathrm{As}$ and $\mathrm{Pb}$ thus do not respond in an entirely similar manner to rain events. This difference in the dynamics cannot be explained based on our data set and prompts the question of why the strong correlation of $\mathrm{DOC}$ with $\mathrm{As}$ and $\mathrm{Pb}$ concentrations observed for the annual low-resolution record is not valid for the rain events.

The weak flushing effect during the spring events indicates a lack of supply of DOC and As caused by low biological productivity early in the year. The stronger flushing effect of $\mathrm{Pb}$ will be discussed further below in relation to the results of pore water analysis. The fall event followed after the summer dry period and the time of highest productivity. When bog water level rises to the surface, the entire previously aerated peat layer becomes hydrologically connected and contributes to near-surface flow. Therefore, a much greater amount of DOC, As and $\mathrm{Pb}$ can be mobilized and exported by such discharge events, resulting in the highest discharge concentrations of all three elements of that year. High-frequency sampling revealed a great dependency of DOC, As and $\mathrm{Pb}$ discharge concentrations on pool exhaustion within the bog. This is evident by decreasing concentrations during an event, as well as a decline in DOC, As and $\mathrm{Pb}$ concentrations when rain events follow up over a short time interval. This exhaustion effect can be explained by a lack of supply of readily mobile element pools when peat layers are hydrologically connected over a longer time period and constant bog water levels. These results are congruent with Rothwell et al. (2007), who sampled subsequent discharge events at a bog-draining stream in fall. In addition, the observed high concentration levels of DOC, As, and $\mathrm{Pb}$ highlight the role of seasonal dynamics of productivity.

Figure 4 displays an element concentration-to-discharge $(c / Q)$ plot for DOC, As and $\mathrm{Pb}$. Here, it is apparent above a threshold of discharge of about $8 \mathrm{~L} \mathrm{~s}^{-1}$ that concentrations of $\mathrm{DOC}, \mathrm{As}$ and $\mathrm{Pb}$ decrease or remain constant. This indicates that at a discharge above $8 \mathrm{~L} \mathrm{~s}^{-1}$ element concentrations become diluted, most likely because all available pools have been connected. As this threshold is distinct and uniform for all three elements, pool exhaustion might be less likely, as the pool size is expected to differ over the vegetation period with a longer supply in summer and fall. Also, mobilization processes are probably different for $\mathrm{DOC}, \mathrm{Pb}$ and As depending on binding types, which result in different responses depending on moisture and temperature preconditions of discharge events. However, rainwater concentrations of DOC, As and $\mathrm{Pb}$ are much lower than pore water concentrations, and hence dilution by precipitation should affect those elements all in the same way, as was observed here. Assuming that surface runoff takes place after saturation of the entire peat layer, the particular discharge at which surface runoff commences and dilution takes place should be similar over the whole year. This conclusion also implies that, at this bog, surface runoff is generated after peat saturation and not through infiltration excess.

\subsection{Peat decomposition and solid-phase $\mathrm{As}, \mathrm{Pb}$ and $\mathrm{Fe}$ concentrations}

Solid-phase $\mathrm{Pb}$ and $\mathrm{As}$ concentration exhibited a similar general trend with depth with higher contents in the uppermost meter (Fig. 5a). Pb concentrations peaked at 40 and $72.5 \mathrm{~cm}$ depth with 1200 and $706 \mathrm{mg} \mathrm{kg}^{-1}$, respectively. These two peaks have been reported before for other bogs in the Harz Mountains (Biester et al., 2012) and can be clearly related to mining activities in the past. Kemptner and Frenzel (2000) related those peaks to regional mining activities in the 12 th/13th century and 17 th century by ${ }^{14} \mathrm{C}$ dating in a bog within $5 \mathrm{~km}$ distance from our sampling site. Due to the strong historic mining influence, the recent decrease in $\mathrm{Pb}$ concentrations in the uppermost centimeter was very pronounced. Also, below $75 \mathrm{~cm}, \mathrm{~Pb}$ concentrations 


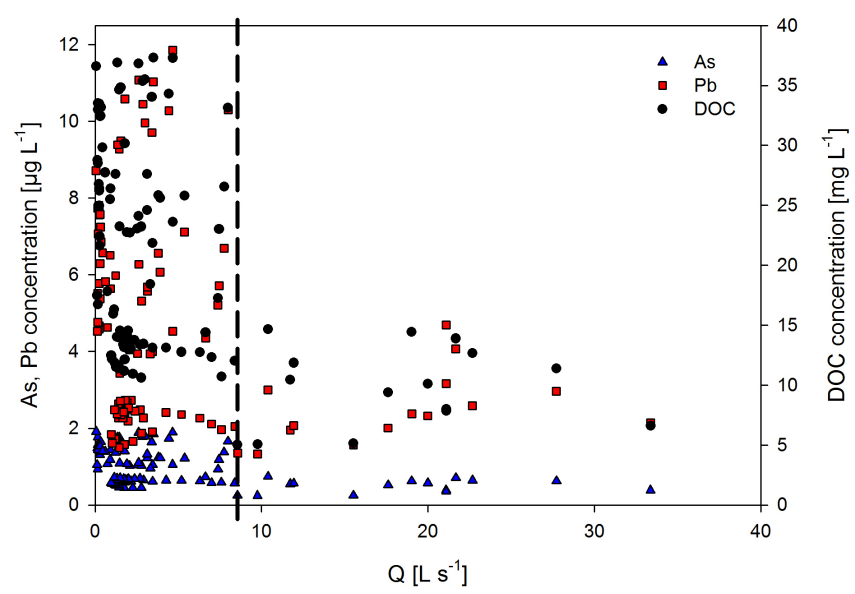

Figure 4. $\mathrm{DOC}, \mathrm{Pb}$ and As stream concentration-to-discharge $(Q)$ plot $(c / Q)$. The black dashed line indicates the threshold discharge value for a general dilution effect.

sharply decreased to non-anthropogenic background levels and $<20 \mathrm{mg} \mathrm{kg}^{-1}$ below $100 \mathrm{~cm}$ depth. Concentrations of As were also highest in the uppermost $75 \mathrm{~cm}$ and show peaks at similar depths as $\mathrm{Pb}$ with maximum concentrations of 65 and $38 \mathrm{mg} \mathrm{kg}^{-1}$ at 30 and $72.5 \mathrm{~cm}$ depth. Peak concentrations of $\mathrm{Pb}$ and As were high, even compared to other contaminated sites (e.g., Rothwell et al., 2009). While $\mathrm{Pb}$ is not a redox-sensitive element, As might be mobilized after deposition and becomes enriched in the near-surface layer due to redox changes, especially when strong water level fluctuations prevail (Rothwell et al., 2010). Because As(V) associates with iron (hydr)oxides, As mobility is known to be controlled by the reductive dissolution of iron (hydr)oxides, which causes the release of As into pore waters and would lead to an enrichment in the near-surface layer along with precipitated iron (hydr)oxides. Fe enrichment at the redox boundary occurs through the upward diffusion of dissolved $\mathrm{Fe}$ (II) and precipitation where oxic conditions prevail. The $\mathrm{Fe}$ depth profile here showed enrichment in the uppermost peat layer with a peak concentration of $5.5 \mathrm{~g} \mathrm{~kg}^{-1}$ at $5 \mathrm{~cm}$ depth and decreasing concentrations down to $1.3 \mathrm{~g} \mathrm{~kg}^{-1}$ at $32.5 \mathrm{~cm}$ depth. Lowest $\mathrm{Fe}$ concentrations were found below $100 \mathrm{~cm}$ depth with concentrations less than $1.3 \mathrm{~g} \mathrm{~kg}^{-1}$. In general Fe concentrations were low compared to other peatlands (Riedel et al., 2013) and much lower than in studies describing $\mathrm{Fe}$ as an important factor for DOC and As retention. Unlike Fe, concentrations of As showed no enrichment in the upper peat layer, indicating that As is not coupled to redox-induced changes of $\mathrm{Fe}$ phases here. We assume that As in our bog is predominately bound to organic matter similar as observed in other peatlands, where As is mainly bound to organic matter by reduced organic sulfur groups under reducing conditions (Langner et al., 2011).

In previous studies, peat decomposition has been found to enrich particular element concentrations through mass loss

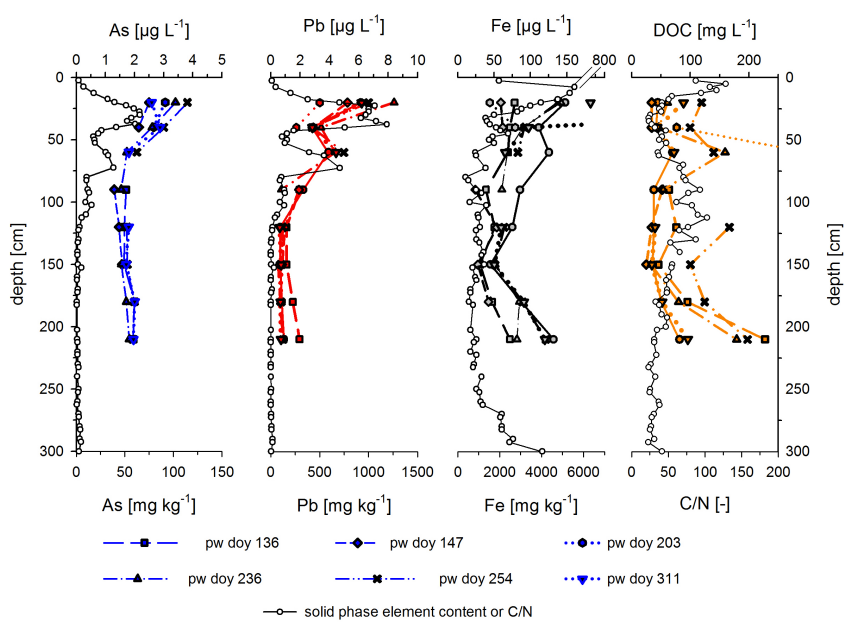

Figure 5. As and $\mathrm{Pb}$ contents of the long peat core taken at the Odersprung bog and carbon nitrogen ratios $(\mathrm{C} / \mathrm{N})$ as indicators of peat decomposition. Pore water concentrations of As (left, blue), $\mathrm{Pb}$ (center left, red), Fe (center right, black) and DOC (right, orange) along a depth profile $(250 \mathrm{~cm})$.

(Biester et al., 2003, 2004, 2014). Figure 5a displays C / N ratios of the organic matter as a proxy for peat decomposition (Kuhry and Vitt, 1996; Broder et al., 2012; Biester et al., 2014). In the upper $12.5 \mathrm{~cm}, \mathrm{C} / \mathrm{N}$ ratios were high (88128) with a distinct decrease to a value of 54 at $15 \mathrm{~cm}$ depth (Fig. 5a). Further below, $\mathrm{C} / \mathrm{N}$ ratios remained low between 23-50 with higher values between 70 and $150 \mathrm{~cm}(50-100)$. This indicates that the upper $15 \mathrm{~cm}$ is less decomposed, while with decreasing $\mathrm{C} / \mathrm{N}$ with depth the degree of decomposition increases, with again a lower degree of decomposition between 70 and $150 \mathrm{~cm}$ depth. A direct influence of decomposition on $\mathrm{As}$ and $\mathrm{Pb}$ distribution was not found here, and concentrations were rather determined by enhanced deposition rates or, in the case of $\mathrm{Fe}$, by redox processes than by peat decomposition.

\subsection{Pore water DOC, As and Pb concentrations}

DOC concentrations in the pore water profile ranged from 20 to $250 \mathrm{mg} \mathrm{L}^{-1}$ (Fig. 5). Highest concentrations were found at the lowermost sample at $225 \mathrm{~cm}$ depth. DOC concentrations in the upper $50 \mathrm{~cm}$, where most discharge is generated, were low in spring under wet conditions (DOY 147: $34-41 \mathrm{mg} \mathrm{L}^{-1}$; Fig. 6) and much higher in fall after rewetting following the dry summer period, with concentrations of $119 \mathrm{mg} \mathrm{L}^{-1}$ at $20 \mathrm{~cm}$ depth and $100 \mathrm{mg} \mathrm{L}^{-1}$ at $40 \mathrm{~cm}$ depth (Fig. 6, DOY 254). In late fall, concentrations decreased again but were still much higher than in spring. This is in line with the recorded seasonal trend of DOC concentrations at the discharging stream and the fact that DOC stream concentrations are dependent on temperature and microbial activity due to build-up of potentially mobile pools (Clark et al., 2005), as well as on the hydraulic connectivity of the near- 

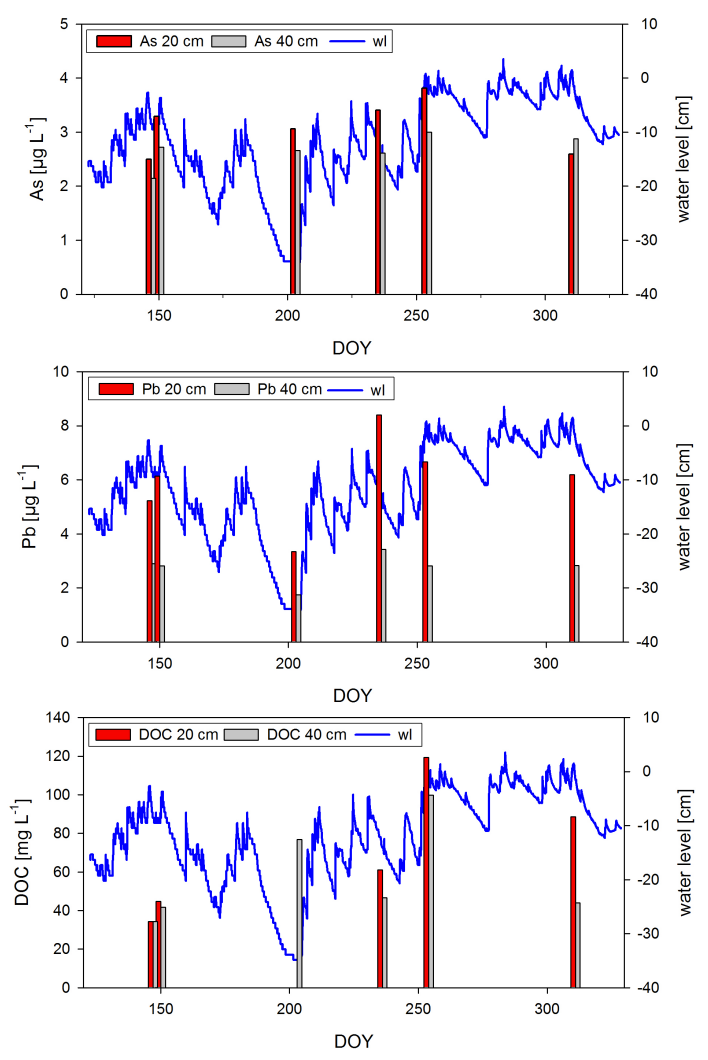

Figure 6. Pore water concentrations of $\mathrm{As}$ (top), $\mathrm{Pb}$ (middle) and DOC (bottom) at 20 and $40 \mathrm{~cm}$ depth over time. The blue line indicates the recorded bog water level (wl).

surface peat layers. Normally, within a couple of weeks after rewetting, acidity is consumed in pore waters through anaerobic respiration processes, such as sulfate- or iron reduction (Fenner and Freeman, 2011). This should favor DOC solubility through higher $\mathrm{pH}$, as well as by release of formerly iron (hydr)oxide-bound DOM (Grybos et al., 2009). Moreover, anaerobic conditions suppress peat mineralization and the described enzymatic latch of phenol oxidase activity favors DOC production after rewetting (Fenner and Freeman, 2011). In line with these assumptions, DOC concentrations were highest in fall several weeks after the summer drought, when the water level had fully recovered again (DOY 254, Fig. 6). However, the lower DOC concentrations measured during this rewetting, at an intermediate water level depth of $14 \mathrm{~cm}$, probably reflect a limitation in DOC supply and an exhaustion of the DOC pool through export, as the sampling only followed two rain events which had already triggered high-DOC stream concentrations.

During the summer drought, the amount of pore water was too low to obtain sufficient sample volume for DOC measurements at $20 \mathrm{~cm}$ depth. At $40 \mathrm{~cm}$ depth DOC concentrations during drought and following rewetting (DOY 254) were higher than in spring and during rewetting (DOY 236). On the one hand, this might contradict the concept of Fenner and Freeman (2011) or Clark et al. (2012), who report low DOC concentrations during drought due to microbial limitations by drought stress and acidification by drought-induced oxidation processes. On the other hand, the measured low $\mathrm{pH}$ $(<4.5 \mathrm{pH})$ in all pore water samples at our site might indicate that the drought acidification effect is not pronounced here, as $\mathrm{pH}$ in our peat is generally low. Moreover, due to the low Fe concentrations in our peat, the effect of DOC immobilization through binding to iron (hydr)oxides during drought and aeration as proposed elsewhere (Riedel et al., 2013) is probably low at our study site. Accordingly, due to the low $\mathrm{pH}$ and the low amount of iron (hydr)oxides at our site suppression of DOC production by drought events seems to be of low importance here and probably in ombrotrophic peatlands in general.

Pore water $\mathrm{As}$ and $\mathrm{Pb}$ concentrations in the Odersprung bog ranged from 1.2 to 3.8 and 0.5 to $8.4 \mu \mathrm{g} \mathrm{L}^{-1}$, respectively (Fig. 5). Concentrations of both $\mathrm{As}$ and $\mathrm{Pb}$ were highest in the uppermost sample at $20 \mathrm{~cm}$ depth. While As was steadily decreasing and leveled out at $70 \mathrm{~cm}$ depth, $\mathrm{Pb}$ concentrations peaked again around $60 \mathrm{~cm}$ depth with $4-5 \mu \mathrm{g} \mathrm{L}^{-1} \mathrm{~Pb}$ before leveling out at about $120 \mathrm{~cm}$ depth. Concentration profiles throughout the year show only small changes in the uppermost samples. Lowest As pore water concentrations at 20 and $40 \mathrm{~cm}$ depth occurred in the first sampling in spring (Fig. 6, DOY 136) with 2.5 and $2.1 \mu \mathrm{g} \mathrm{L}^{-1}$, respectively. At the end of the summer drought, As concentrations remained at around $3 \mu \mathrm{g} \mathrm{L}-1$ (DOY 203), while Pb pore water concentrations decreased from about $6 \mu \mathrm{gL}^{-1}(20 \mathrm{~cm}$ depth) and $3 \mu \mathrm{g} \mathrm{L}^{-1}$ (40 cm depth) to lowest annual concentrations of 3.3 and $1.7 \mu \mathrm{g} \mathrm{L}{ }^{-1} \mathrm{~Pb}$, respectively, during summer drought. While highest $\mathrm{Pb}$ concentrations $\left(8.4 \mu \mathrm{g} \mathrm{L}^{-1}\right)$ were measured at the beginning of fall (Fig. 6, DOY 236), when the water level had not yet fully recovered, highest As concentrations occurred after the complete rewetting of the bog in September congruently with DOC concentrations (DOY 254). $\mathrm{Pb}$ concentrations at $40 \mathrm{~cm}$ depth were constant with the exception of a slight decrease during summer drought (DOY 311: $\sim 3 \mu \mathrm{g} \mathrm{L}^{-1}$ ). The very high $\mathrm{Pb}$ concentrations measured during water table recovery might be due to mobilization of a $\mathrm{Pb}$ pool which built up during drought in the most reactive nearsurface peat layer by microbial decomposition or mineralization processes. This assumption might also explain the decoupling of $\mathrm{DOC}$ and $\mathrm{Pb}$ export apparent at discharge events after dry preconditions, as a readily solubilized $\mathrm{Pb}$ pool is easily flushed. Moreover, it explains the absence of the initial dilution effect as seen in DOC stream concentrations. Furthermore, the DOC pool increases after drought, when wet conditions prevail again, explaining the lag time of DOC peak concentrations in pore waters.

The decreasing $\mathrm{Pb}$ concentrations with depth allow determination of the discharge water source. The hydrologic response of the bog discharge was characteristic for a rapid near-surface runoff. Comparing absolute concentrations in pore water and discharging water, the high $\mathrm{Pb}$ concentrations 

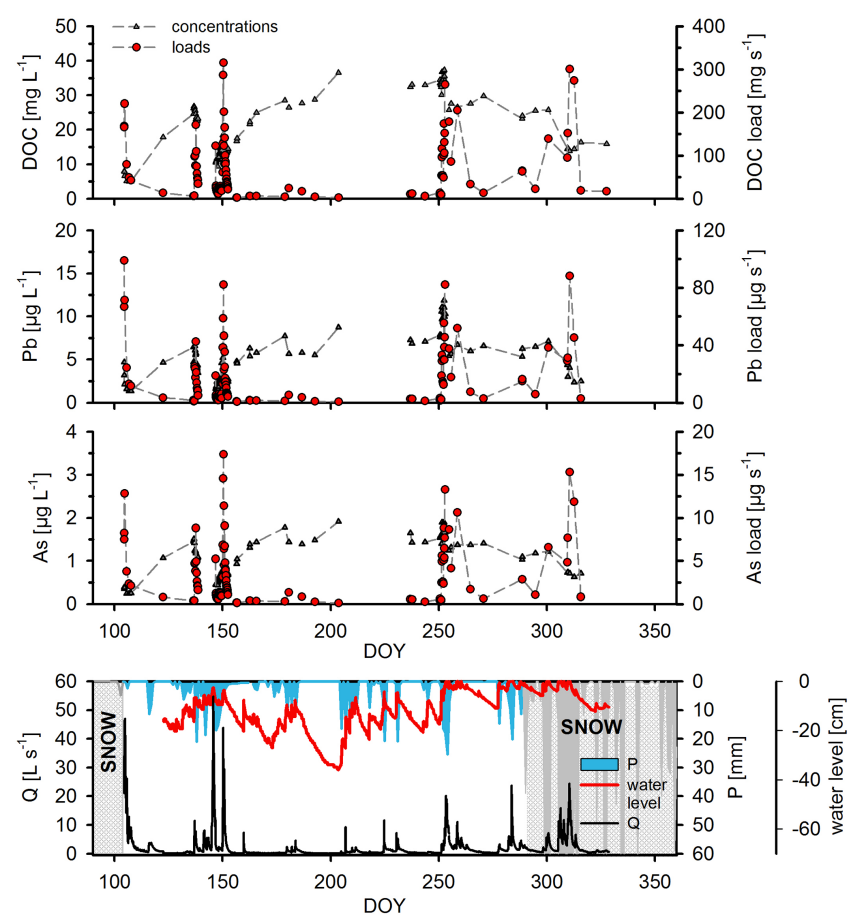

Figure 7. Top three panels: concentration record and instantaneous loads of $\mathrm{DOC}, \mathrm{Pb}$ and $\mathrm{As}$ at the bog outlet. Bottom panel: annual records of bog water level, precipitation and discharge.

Table 1. Seasonal distribution of discharge, DOC, As and $\mathrm{Pb}$ export fluxes at the Odersprung catchment.

\begin{tabular}{lrrrrr}
\hline & $\begin{array}{r}\text { Record time } \\
\%\end{array}$ & $\begin{array}{c}Q \\
\%\end{array}$ & $\begin{array}{r}\text { DOC export } \\
\%\end{array}$ & $\begin{array}{r}\text { As export } \\
\%\end{array}$ & $\begin{array}{r}\text { Pb export } \\
\%\end{array}$ \\
\hline Snowmelt & 7.6 & 19.8 & 7.4 & 11.1 & 7.2 \\
Spring & 21.3 & 25.5 & 19.2 & 15.3 & 19.1 \\
Summer & 35.6 & 10.8 & 12.5 & 10.2 & 12.0 \\
Fall & 35.6 & 47.5 & 60.8 & 63.4 & 61.7 \\
\hline
\end{tabular}

of more than $10 \mu \mathrm{g} \mathrm{L}^{-1}$ in runoff during the fall rain event can only be generated in the uppermost part of the bog, where $\mathrm{Pb}$ concentrations were highest. Following this assumption, the low-flow concentrations must have also been generated in the upper part of the peat profile as $\mathrm{Pb}$ concentrations below $1 \mathrm{~m}$ depth were too low to generate the observed $\mathrm{Pb}$ concentrations in discharge. The variable $\mathrm{Pb}$ concentrations at different flow conditions are attributed to different water levels, which affect variable parts of the $\mathrm{Pb}$ pool in the acrotelm and are thus able to mobilize different amounts of $\mathrm{Pb}$. This also indicates that, in line with the hydrologic discharge response, low-flow discharge is generated from upper peat layers and not from seeping water originating from the deep peat sections.
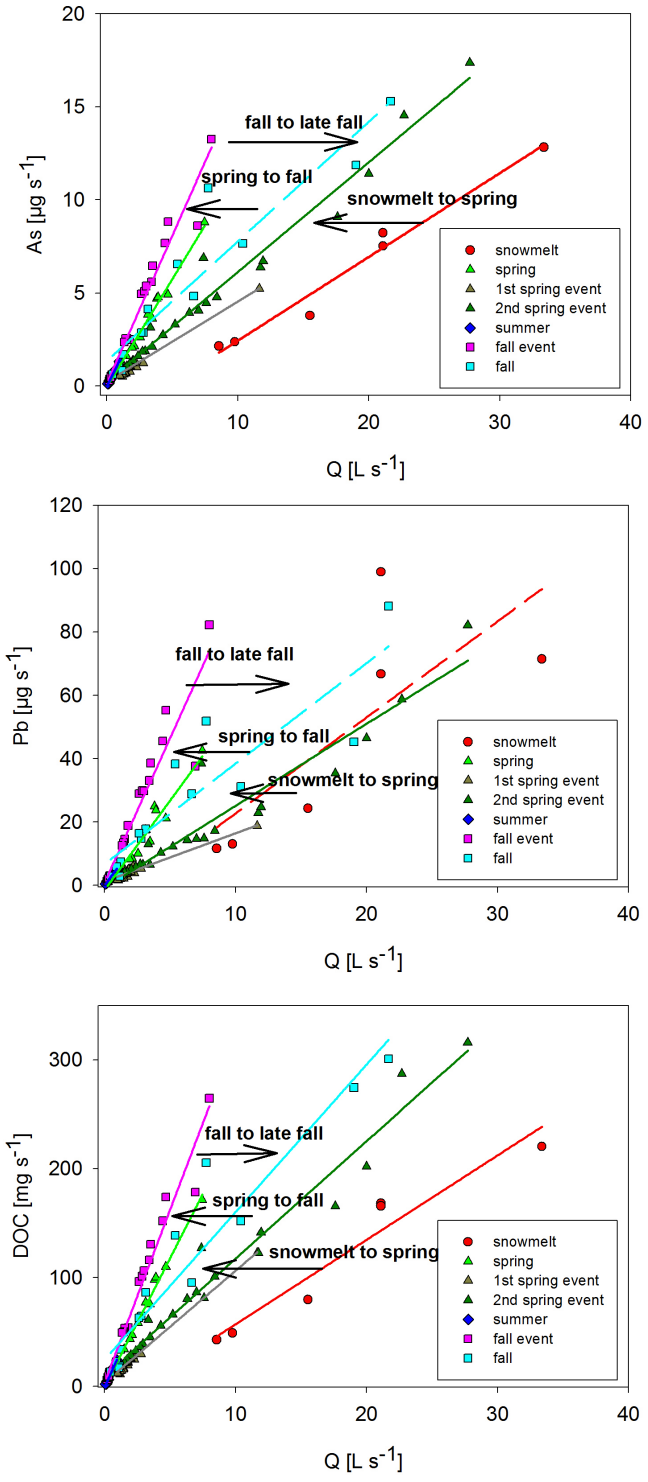

Figure 8. As (top), $\mathrm{Pb}$ (middle) and DOC (bottom) loadings to discharge $(Q)$ plots divided by season and event sampling. Regression lines with $R^{2}>0.90$ are plotted with a solid line, $R^{2}<0.9$ are plotted with a dashed line.

\subsection{Fluxes and inventory estimations}

While DOC and As concentrations were highest in summer and seemed to be more dependent on temperature, DOC, As and $\mathrm{Pb}$ fluxes were controlled not by the concentration changes over the year but mainly by discharge (Fig. 7). This dependency is valid up to a discharge of $8 \mathrm{~L} \mathrm{~s}^{-1}$, while at a higher discharge, dilution is observed. Highest element fluxes occurred during high-discharge events in spring and fall and during snowmelt. Flux calculations show that $10 \%$ of the monitoring time span, when highest discharge was recorded, contributed 39, 40 and $43 \%$ of the annual DOC, $\mathrm{As}$ and $\mathrm{Pb}$ export, respectively. Similar patterns have been 
Table 2. Estimated mean DOC, As and $\mathrm{Pb}$ export in 2013 and element inventories in the upper $30 \mathrm{~cm}$ of peat. Uncertainties were estimated by the standard deviation of flux calculations and element inventories calculated for each core.

\begin{tabular}{lccccc}
\hline & \multicolumn{2}{c}{ Mean annual fluxes } & \multicolumn{2}{c}{ Peat inventory } \\
$\mathrm{g} \mathrm{ha}^{-1} \mathrm{a}^{-1}$ & $\mathrm{~kg} \mathrm{bog}^{-1} \mathrm{a}^{-1}$ & $\mathrm{~g} \mathrm{~m}^{-2}$ & $166.89 \times 10^{3}$ & $\begin{array}{c}\text { Export } \\
\text { \%oo of inventory }\end{array}$ \\
\hline DOC & $154.79 \times 10^{3}$ & 773.93 & 16689 & 166.93 \\
uncertainty & $88-221 \times 10^{3}$ & $441-1107$ & $(15336-17417)$ & $\left(153.36 \times 10^{3}-174.170 \times 10^{3}\right)$ & $(0.89-1.01)$ \\
As & 7.8 & 0.04 & 0.91 & 9.1 & 0.85 \\
uncertainty & $4.8-10.8$ & $0.02-0.06$ & $(0.64-1.17)$ & $(6.4-11.7)$ & $(0.66-1.22)$ \\
Pb & 39.2 & 0.2 & 13.98 & 139.8 & 0.27 \\
uncertainty & $23.1-55.3$ & $0.12-0.28$ & $(7.47-24.02)$ & $(74.7-240.2)$ & $(0.16-0.51)$ \\
\hline
\end{tabular}

${ }^{\mathrm{a}}$ Upper $30 \mathrm{~cm} ;{ }^{\mathrm{b}}$ total $\mathrm{C}$ for peat inventory, respectively.

described by Koehler et al. (2009) for DOC fluxes from a blanket bog in Ireland. Clark et al. (2007) calculated that $10 \%$ of the monitoring time span including highest discharge contributed $50 \%$ of the annual DOC export, and Hinton et al. (1997) estimated $41-57 \%$ of annual DOC export by $10 \%$ of the time of the highest discharge. When separating the annual hydrograph record in storm-flow and low-flow conditions (boundary at $0.3 \mathrm{~L} \mathrm{~s}^{-1}$ by visual examination), $72 \%$ of the record exhibited high-discharge conditions, which contributed $97.6 \%$ of total annual discharge and about $96 \%$ of annual $\mathrm{As}, \mathrm{Pb}$ and $\mathrm{DOC}$ export.

This flux calculations implicate that high-discharge events contribute over-proportionally to element exports in a short time period. While low-flow conditions generate high element concentrations, greater discharge does not primarily dilute element concentrations but in fact connects additional pools to discharge, which results in higher fluxes. To conclude, as different $\mathrm{DOC}, \mathrm{As}$, and $\mathrm{Pb}$ pools (i.e., different peat layers) correspond to different hydrologic conditions, different linkages to element exports are also likely. If low-flow discharge is generated in the lower acrotelm, not only general pool sizes but also mobilization conditions are different, i.e., different $\mathrm{pH}$, redox and DOC quality. Further insight into differences between low-flow and high-flow export dynamics might be gained through $\mathrm{Pb}$ isotope determinations (see Klaminder et al., 2008), a determination of DOC age or DOC characterization.

The importance of high-discharge events to $\mathrm{Pb}, \mathrm{As}$ and DOC exports becomes more relevant in view of changing climate conditions with more frequent heavy rain events in this region. Furthermore, the time of year at which rain events will occur in the future is crucial. A data separation by season indicates that fall contributes to the largest extend to annual element export followed by spring and similar ranges in summer and snowmelt (Table 1). This pattern is in line with the assumption that higher microbial activity on the one hand and elevated discharge, which flushes the acrotelm, on the other favor DOC, As and $\mathrm{Pb}$ export. The lower fluxes during summer are attributed to prevailing low-flow, dry conditions. Figure 8 displays discharge to element loading plots separated by season and high-discharge event sampling. It highlights higher loadings at the same discharge volume dependent on season by a steeper increase in the regression line. In general, element loadings are lowest at snowmelt and increase over the year, with highest loadings during the fall event. At the end of the year, loadings decrease again. While this general trend is similar for DOC and As, Fig. 8 also shows that $\mathrm{Pb}$ loadings during snowmelt and the second spring event are quite similar and that concentrations are less dependent on discharge volume, indicated by lower $R^{2}$ values of the regression lines.

The annual DOC export from the investigated bog catchment can be estimated to $155 \pm 67 \mathrm{~kg} \mathrm{Cha}^{-1} \mathrm{a}^{-1}$ (Table 2) and is similar to values from other studies (Worrall et al., 2003; Koehler et al., 2009). As the upstream catchment is completely snow-covered during winter, including the stream outlet at the bog, no flux quantification during winter is possible. It can be speculated, though, that fluxes are probably low due to low temperatures and low-flow conditions during the winter season.

Aqueous exports of $\mathrm{As}$ and $\mathrm{Pb}$ were calculated to $7.8 \pm 3.0 \mathrm{~g} \mathrm{As} \mathrm{ha}^{-1} \mathrm{a}^{-1}$ and $39 \pm 16 \mathrm{~g} \mathrm{~Pb} \mathrm{ha}^{-1} \mathrm{a}^{-1}$. Annual $\mathrm{Pb}$ export was in the same range as values reported by Rothwell et al. (2011), with annual aqueous $\mathrm{Pb}$ export of $55 \pm 18 \mathrm{~g} \mathrm{~Pb} \mathrm{ha}^{-1} \mathrm{a}^{-1}$ from a contaminated eroded ombrotrophic peatland. The authors also highlighted the importance of particulate $\mathrm{Pb}$ export for peatland systems, which needs to be considered when estimating total $\mathrm{Pb}$ export. The calculated aqueous As export from our site was much lower than that reported by Rothwell et al. (2011; $47.1 \pm 9.9 \mathrm{~g} \mathrm{As} \mathrm{ha}^{-1} \mathrm{a}^{-1}$ ), in spite of higher As contents in our peat. This might be due to the eroded nature of their sampled bog and the prevailing post-depositional mobilization of As in peat due accelerated water table drawdowns and a consequent binding to iron (hydr)oxides (Rothwell et al., 2010).

As and $\mathrm{Pb}$ inventories were calculated based on the median element contents in the upper $30 \mathrm{~cm}$ of the 16 analyzed cores and were $0.91 \mathrm{~g} \mathrm{As} \mathrm{m}^{-2}\left(0.64-1.17 \mathrm{~g} \mathrm{~m}^{-2}\right)$ and $13.98 \mathrm{~g} \mathrm{~Pb} \mathrm{~m}^{-2}$ (7.47-24.02 $\mathrm{g} \mathrm{Pb} \mathrm{m}^{-2}$ ), respectively (Table 2). Element contents in the upper $30 \mathrm{~cm}$ varied over a 
wide range, pointing out the importance of a multi-core approach for calculating peatland element inventories. Rothwell et al. (2010) calculated a storage of $0.19-0.44 \mathrm{~g} \mathrm{As} \mathrm{m}^{-2}$ and $12.2-13.5 \mathrm{~g} \mathrm{~Pb} \mathrm{~m}^{-2}$ in another contaminated peatland. While our calculated $\mathrm{Pb}$ inventories are similar, As inventories are higher than those reported by Rothwell et al. (2010). When referring annual fluxes to the bog area of the catchment $0.04 \mathrm{~kg} \mathrm{As} \mathrm{a}^{-1}$ and $0.2 \mathrm{~kg} \mathrm{~Pb} \mathrm{a}^{-1}$ were exported in 2013 by the bog drainage. This equates to 0.85 and $0.27 \%$ of the calculated $\mathrm{As}$ and $\mathrm{Pb}$ inventories, respectively (Table 2). Even though conclusions based on a 1-year data set are limited and uncertainties are high, it becomes clear that As seemed to be more mobile than $\mathrm{Pb}$. Neglecting future element deposition and changing export conditions it would take more than 1000 years to deplete As pools and more than 3000 years for $\mathrm{Pb}$ pools stored within this polluted peatland. Furthermore, the observed element content variation among all cores might also implicate differences in pore water concentration levels within the stream catchment.

\section{Conclusions}

Our results highlight the importance of comprehensive field studies to gain further understanding of the generation and controls of element exports from peatlands. The combination of pore water and discharge data showed that $\mathrm{As}$ and $\mathrm{Pb}$ exports are dependent on not only the amount of precipitation and discharge but also on the frequency and depth of water table fluctuations, as well as the extent of pool connectivity in the acrotelm. This has been demonstrated by higher $\mathrm{As}$ and $\mathrm{Pb}$ concentrations and exponential increase in export at high-discharge events, especially after a longer dry period and higher temperatures. A distinct bog-specific discharge threshold of $8 \mathrm{~L} \mathrm{~s}^{-1}$ was observed, which indicates a connection of all available pools. This threshold presumably depends mainly on the size of the bog and drainage conditions. Significant correlations of annual $\mathrm{As}, \mathrm{Pb}$ and $\mathrm{DOC}$ concentrations in discharge points to transport of $\mathrm{As}$ and $\mathrm{Pb}$ as organic complexes with decoupling of $\mathrm{Pb}$ from DOC concentrations during storm events following dry preconditions. Comparison of the annual bog $\mathrm{As}$ and $\mathrm{Pb}$ export with element inventories indicates that As is much stronger mobilized than $\mathrm{Pb}$, with annual fluxes accounting for 0.85 and $0.27 \%$ of the total $\mathrm{As}$ and $\mathrm{Pb}$ inventory, respectively. Results also point out the over-proportional contribution of highdischarge events to $\mathrm{As}, \mathrm{Pb}$ and $\mathrm{DOC}$ annual export. The challenge for prospective research is to unravel the biogeochemical effects of short-term water level fluctuations on trace element and DOC mobilization processes within peatlands in order to further improve parameterization of peatland catchment models.

\section{The Supplement related to this article is available online} at doi:10.5194/bg-12-4651-2015-supplement.
Acknowledgements. This work was funded by the NTH graduate school "GeoFluxes" of the federal state of Lower Saxony, Germany. We are grateful to Nationalpark Harz for giving access to the site. The authors thank Adelina Calean and Petra Schmidt, Johan Rydberg, Julian Fricke, Hannah Huster, Ricarda Rissel and Tabea Neudeck for help with lab and field work.

Edited by: B. A. Pellerin

\section{References}

Aitkenhead, J. A., Hope, D., and Billett, M. F.: The relationship between dissolved organic carbon in stream water and soil organic carbon pools at different spatial scales, Hydrol. Process., 13, 1289-1302, 1999.

Bauer, M. and Blodau, C.: Arsenic distribution in the dissolved, colloidal and particulate size fraction of experimental solutions rich in dissolved organic matter and ferric iron, Geochim. Cosmochim. Ac., 73, 529-542, doi:10.1016/j.gca.2008.10.030, 2009.

Baumann, K.: Entwicklung der Moorvegetation im Nationalpark Harz, 1th ed., Schriftenreihe aus dem Nationalpark Harz, 4, 244 pp., 2009.

Beug, H.-J., Henrion, I., and Schmüser, A.: Landschaftsgeschichte im Hochharz, Die Entwicklung der Wälder und Mooreseit dem Ende der letzten Eiszeit, Goslar, 460 pp., 1999.

Biester, H., Martinez-Cortizas, A., Birkenstock, S., and Kilian, R.: Effect of Peat Decomposition and Mass Loss on Historic Mercury Records in Peat Bogs from Patagonia, Environ. Sci. Technol., 37, 32-39, doi:10.1021/es025657u, 2003.

Biester, H., Keppler, F., Putschew, A., Martinez-Cortizas, A., and Petri, M.: Halogen Retention, Organohalogens, and the Role of Organic Matter Decomposition on Halogen Enrichment in Two Chilean Peat Bogs, Environ. Sci. Technol., 38, 1984-1991, doi:10.1021/es0348492, 2004.

Biester, H., Hermanns, Y.-M., and Martinez Cortizas, A.: The influence of organic matter decay on the distribution of major and trace elements in ombrotrophic mires - a case study from the Harz Mountains, Geochim. Cosmochim. Ac., 84, 126-136, doi:10.1016/j.gca.2012.01.003, 2012.

Biester, H., Knorr, K.-H., Schellekens, J., Basler, A., and Hermanns, Y.-M.: Comparison of different methods to determine the degree of peat decomposition in peat bogs, Biogeosciences, 11, 26912707, doi:10.5194/bg-11-2691-2014, 2014.

Bindler, R.: Mired in the past - looking to the future: Geochemistry of peat and the analysis of past environmental changes, Global Planet. Change, 53, 209-221, doi:10.1016/j.gloplacha.2006.03.004, 2006.

Blodau, C., Fulda, B., Bauer, M., and Knorr, K.-H.: Arsenic speciation and turnover in intact organic soil mesocosms during experimental drought and rewetting, Geochim. Cosmochim. Ac., 72, 3991-4007, doi:10.1016/j.gca.2008.04.040, 2008.

Broder, T., Blodau, C., Biester, H., and Knorr, K. H.: Peat decomposition records in three pristine ombrotrophic bogs in southern Patagonia, Biogeosciences, 9, 1479-1491, doi:10.5194/bg9-1479-2012, 2012.

Buschmann, J., Kappeler, A., Lindauer, U., Kistler, D., Berg, M., and Sigg, L.: Arsenite and Arsenate Binding to Dissolved Humic 
Acids: Influence of pH, Type of Humic Acid, and Aluminum, Environ. Sci. Technol., 40, 6015-6020, doi:10.1021/es061057+, 2006.

Cheburkin, A. and Shotyk, W.: An Energy-dispersive Miniprobe Multielement Analyzer (EMMA) for direct analysis of $\mathrm{Pb}$ and other trace elements in peats, Fresen J. Anal. Chem., 354, 688691, doi:10.1007/s0021663540688, 1996.

Chow, A. T., Tanji, K. K., and Gao, S.: Production of dissolved organic carbon (DOC) and trihalomethane (THM) precursor from peat soils, Water Res., 37, 4475-4485, doi:10.1016/S00431354(03)00437-8, 2003

Clark, J. M., Chapman, P. J., Adamson, J. K., and Lane, S. N.: Influence of drought-induced acidification on the mobility of dissolved organic carbon in peat soils, Glob. Change Biol., 11, 791809, doi:10.1111/j.1365-2486.2005.00937.x, 2005.

Clark, J. M., Lane, S. N., Chapman, P. J., and Adamson, J. K.: Export of dissolved organic carbon from an upland peatland during storm events: Implications for flux estimates, J. Hydrol., 347, 438-447, doi:10.1016/j.jhydrol.2007.09.030, 2007.

Clark, J. M., Lane, S. N., Chapman, P. J., and Adamson, J. K.: Link between DOC in near surface peat and stream water in an upland catchment: Biogeochemistry of forested ecosystem - Selected papers from BIOGEOMON, the 5th International Symposium on Ecosystem Behaviour, held at the University of California, Santa Cruz, on June 25-30, 2006, Sci. Total Environ., 404, 308-315, doi:10.1016/j.scitotenv.2007.11.002, 2008.

Clark, J. M., Heinemeyer, A., Martin, P., and Bottrell, S. H.: Processes controlling DOC in pore water during simulated drought cycles in six different UK peats, Biogeochemistry, 109, 253-270, doi:10.1007/s10533-011-9624-9, 2012.

Daniels, S., Agnew, C., Allott, T., and Evans, M.: Water table variability and runoff generation in an eroded peatland, South Pennines, UK, J. Hydrol., 361, 214-226, doi:10.1016/j.jhydrol.2008.07.042, 2008 .

Dyson, K. E., Billett, M. F., Dinsmore, K. J., Harvey, F., Thomson, A. M., Piirainen, S., and Kortelainen, P.: Release of aquatic carbon from two peatland catchments in E. Finland during the spring snowmelt period, Biogeochemistry, 103, 125-142, 2011.

Evans, C. D., Monteith, D. T., and Cooper, D. M.: Long-term increases in surface water dissolved organic carbon: Observations, possible causes and environmental impacts, Environ. Pollut., 137, 55-71, doi:10.1016/j.envpol.2004.12.031, 2005.

Evans, C. D., Jones, T. G., Burden, A., Ostle, N., Zieliński, P., Cooper, M. D. A., Peacock, M., Clark, J. M., Oulehle, F., Cooper, D., and Freeman, C.: Acidity controls on dissolved organic carbon mobility in organic soils, Glob. Change Biol., 18, 33173331, doi:10.1111/j.1365-2486.2012.02794.x, 2012.

Evans, M. G., Burt, T. P., Holden, J., and Adamson, J. K.: Runoff generation and water table fluctuations in blanket peat: Evidence from UK data spanning the dry summer of 1995, J. Hydrol., 221, 141-160, 1999.

Fenner, N. and Freeman, C.: Drought-induced carbon loss in peatlands, Nat. Geosci., 4, 895-900, doi:10.1038/ngeo1323, 2011.

Freeman, C., Evans, C. D., Monteith, D. T., Reynolds, B., and Fenner, N.: Export of organic carbon from peat soils, Nature, 412, 785-785, 2001.

Grybos, M., Davranche, M., Gruau, G., and Petitjean, P.: Is trace metal release in wetland soils controlled by organic matter mobil- ity or Fe-oxyhydroxides reduction?, J. Colloid. Interf. Sci., 314 490-501, doi:10.1016/j.jcis.2007.04.062, 2007.

Grybos, M., Davranche, M., Gruau, G., Petitjean, P., and Pédrot, M.: Increasing $\mathrm{pH}$ drives organic matter solubilization from wetland soils under reducing conditions, Geoderma, 154, 13-19, doi:10.1016/j.geoderma.2009.09.001, 2009.

Hinton, M. J., Schiff, S. L., and English, M. C.: The significance of storms for the concentration and export of dissolved organic carbon from two Precambrian Shield catchments, Biogeochemistry, 36, 67-88, 1997.

Holden, J. and Burt, T. P.: Runoff production in blanket peat covered catchments, Water Resour. Res., 39, SWC61-SWC69, doi:10.1029/2002WR001956, 2003.

Hongve, D., Riise, G., and Kristiansen, J. F.: Increased colour and organic acid concentrations in Norwegian forest lakes and drinking water ? a result of increased precipitation?, Aquat. Sci., 66, 231-238, doi:10.1007/s00027-004-0708-7, 2004.

Hope, D., Billett, M. F., and Cresser, M. S.: Exports of organic carbon in two river systems in NE Scotland, J. Hydrol., 193, 61-82, doi:10.1016/S0022-1694(96)03150-2, 1997.

IPCC (Ed.): Climate Change 2013: The Physical Science Basis. Contribution of Working Group I to the Fifth Assessment Report of the Intergovernmental Panel on Climate Change, Cambridge University Press, Cambridge, United Kingdom and New York, NY, USA, 1535 pp., 2013.

Jordan, R. N., Yonge, D. R., and Hathhorn, W. E.: Enhanced mobility of $\mathrm{Pb}$ in the presence of dissolved natural organic matter, J. Contam. Hydrol., 29, 59-80, 1997.

Kempter, H. and Frenzel, B.: The impact of early mining and smelting on the local tropospheric aerosol detected in ombrotrophic peat bogs in the Harz, Germany, Water Air Soil. Poll., 121, 93 108, doi:10.1023/A:1005253716497, 2000.

Klaminder, J., Bindler, R., and Renberg, I.: The biogeochemistry of atmospherically derived $\mathrm{Pb}$ in the boreal forest of Sweden, Appl. Geochem., 23, 2922-2931, doi:10.1016/j.apgeochem.2008.04.007, 2008.

Knorr, K.-H.: DOC-dynamics in a small headwater catchment as driven by redox fluctuations and hydrological flow paths - are DOC exports mediated by iron reduction/oxidation cycles?, Biogeosciences, 10, 891-904, doi:10.5194/bg-10-891-2013, 2013.

Koehler, A.-K., Murphy, K., Kiely, G., and Sottocornola, M.: Seasonal variation of DOC concentration and annual loss of DOC from an Atlantic blanket bog in South Western Ireland, Biogeochemistry, 95, 231-242, doi:10.1007/s10533-009-9333-9, 2009.

Köhler, S. J., Buffam, I., Laudon, H., and Bishop, K. H.: Climate's control of intra-annual and interannual variability of total organic carbon concentration and flux in two contrasting boreal landscape elements, J. Geophys. Res., 113, G03012, doi:10.1029/2007JG000629, 2008.

Kokfelt, U., Rosén, P., Schoning, K., Christensen, T. R., Förster, J., Karlsson, J., Reuss, N., Rundgren, M., Callaghan, T. V., Jonasson, C., and Hammarlund, D.: Ecosystem responses to increased precipitation and permafrost decay in subarctic Sweden inferred from peat and lake sediments, Glob. Change Biol., 15, 1652 1663, doi:10.1111/j.1365-2486.2009.01880.x, 2009.

Kuhry, P. and Vitt, D. H.: Fossil carbon/nitrogen ratios as a measure of peat decomposition, Ecology, 77, 271-275, 1996. 
Langner, P., Mikutta, C., and Kretzschmar, R.: Arsenic sequestration by organic sulphur in peat, Nat. Geosci., 5, 66-73, doi:10.1038/ngeo1329, 2011.

Langner, P., Mikutta, C., and Kretzschmar, R.: Oxidation of Organosulfur-Coordinated Arsenic and Realgar in Peat: Implications for the Fate of Arsenic, Environ. Sci. Technol., 48, 22812289, doi:10.1021/es4049785, 2014.

Laudon, H., Köhler, S., and Buffam, I.: Seasonal TOC export from seven boreal catchments in northern Sweden, Aquat. Sci., 66, 223-230, doi:10.1007/s00027-004-0700-2, 2004.

Laudon, H., Berggren, M., Ågren, A., Buffam, I., Bishop, K., Grabs, T., Jansson, M., and Köhler, S.: Patterns and Dynamics of Dissolved Organic Carbon (DOC) in Boreal Streams: The Role of Processes, Connectivity, and Scaling, Ecosystems, 14, 880-893, doi:10.1007/s10021-011-9452-8, 2011.

Littlewood, I. G.: Estimating contaminant loads in rivers: a review, Report - UK Institute of Hydrology, 117, 81 pp., 1992.

Lofts, S., Tipping, E., and Hamilton-Taylor, J.: The Chemical Speciation of Fe(III) in Freshwaters, Aquat. Geochem., 14, 337-358, doi:10.1007/s10498-008-9040-5, 2008.

Monteith, D. T., Stoddard, J. L., Evans, C. D., Wit, H. A. de, Forsius, M., Høgåsen, T., Wilander, A., Skjelkvåle, B. L., Jeffries, D. S., Vuorenmaa, J., Keller, B., Kopácek, J., and Vesely, J.: Dissolved organic carbon trends resulting from changes in atmospheric deposition chemistry, Nature, 450, 537-540, doi:10.1038/nature06316, 2007.

Neubauer, E., Köhler, S. J., Kammer, F. von der, Laudon, H., and Hofmann, T.: Effect of $\mathrm{pH}$ and Stream Order on Iron and Arsenic Speciation in Boreal Catchments, Environ. Sci. Technol., 47, 7120-7128, doi:10.1021/es401193j, 2013.

Riedel, T., Zak, D., Biester, H., and Dittmar, T.: Iron traps terrestrially derived dissolved organic matter at redox interfaces, P. Natl. Acad. Sci. USA, 110, 10101-10105, doi:10.1073/pnas.1221487110, 2013.

Ritter, K., Aiken, G. R., Ranville, J. F., Bauer, M., and Macalady, D. L.: Evidence for the Aquatic Binding of Arsenate by Natural Organic Matter-Suspended Fe(III), Environ. Sci. Technol., 40, 5380-5387, doi:10.1021/es0519334, 2006.

Rothwell, J., Evans, M., Daniels, S., and Allott, T.: Baseflow and stormflow metal concentrations in streams draining contaminated peat moorlands in the Peak District National Park (UK), J. Hydrol., 341, 90-104, doi:10.1016/j.jhydrol.2007.05.004, 2007.

Rothwell, J., Taylor, K., Ander, E., Evans, M., Daniels, S., and Allott, T.: Arsenic retention and release in ombrotrophic peatlands, Sci. Total Environ., 407, 1405-1417, doi:10.1016/j.scitotenv.2008.10.015, 2009.

Rothwell, J. J., Taylor, K. G., Chenery, S. R. N., Cundy, A. B., Evans, M. G., and Allott, T. E. H.: Storage and behavior of $\mathrm{As}, \mathrm{Sb}, \mathrm{Pb}$, and $\mathrm{Cu}$ in ombrotrophic peat bogs under contrasting water table conditions, Environ. Sci. Technol., 44, 8497-8502, 2010.

Rothwell, J. J., Taylor, K. G., Evans, M. G., and Allott, T. E. H.: Contrasting controls on arsenic and lead budgets for a degraded peatland catchment in Northern England, Environ. Pollut., 159, 3129-3133, 2011.
Seibert, J., Grabs, T., Köhler, S., Laudon, H., Winterdahl, M., and Bishop, K.: Linking soil- and stream-water chemistry based on a Riparian Flow-Concentration Integration Model, Hydrol. Earth Syst. Sc., 13, 2287-2297, 2009.

Shotyk, W.: History of Atmospheric Lead Deposition Since $1237014 \mathrm{C}$ yr BP from a Peat Bog, Jura Mountains, Switzerland, Science, 281, 1635-1640, doi:10.1126/science.281.5383.1635, 1998.

Singh, S., Inamdar, S., Mitchell, M., and McHale, P.: Seasonal pattern of dissolved organic matter (DOM) in watershed sources: influence of hydrologic flow paths and autumn leaf fall, Biogeochemistry, 118, 321-337, doi:10.1007/s10533-013-9934-1, 2014.

Thomas Arrigo, L. K., Mikutta, C., Byrne, J., Barmettler, K., Kappler, A., and Kretzschmar, R.: Iron and Arsenic Speciation and Distribution in Organic Flocs from Streambeds of an ArsenicEnriched Peatland, Environ. Sci. Technol., 48, 13218-13228, doi:10.1021/es503550g, 2014.

Tipping, E.: Humic ion-binding model VI: An improved description of the interactions of protons and metal ions with humic substances, Aquat. Geochem., 4, 3-47, doi:10.1023/A:1009627214459, 1998.

Tipping, E., Rey-Castro, C., Bryan, S. E., and HamiltonTaylor, J.: Al(III) and Fe(III) binding by humic substances in freshwaters, and implications for trace metal speciation, Geochim. Cosmochim. Ac., 66, 3211-3224, doi:10.1016/S00167037(02)00930-4, 2002.

Tipping, E., Rieuwerts, J., Pan, G., Ashmore, M., Lofts, S., Hill, M., Farago, M., and Thornton, I.: The solid-solution partitioning of heavy metals $(\mathrm{Cu}, \mathrm{Zn}, \mathrm{Cd}, \mathrm{Pb})$ in upland soils of England and Wales, Environ. Pollut., 125, 213-225, doi:10.1016/S02697491(03)00058-7, 2003.

Vinogradoff, S. I., Graham, M. C., Thornton, G. J. P., Dunn, S. M., Bacon, J. R., and Farmer, J. G.: Investigation of the concentration and isotopic composition of inputs and outputs of $\mathrm{Pb}$ in waters at an upland catchment in NE Scotland, J. Environ. Monitor., 7, 431-444, doi:10.1039/b415642k, 2005.

Walling, D. E. and Webb, B. W.: Estimating the discharge of contaminants to coastal waters by rivers: Some cautionary comments, Mar. Pollut. Bull., 16, 488-492, 1985.

WHO: Guidelines for drinking-water quality, 4th ed., World Health Organization, Geneva, 541 pp., 541, 2011.

Worrall, F., Burt, T. P., Jaeban, R. Y., Warburton, J., and Shedden, R.: Release of dissolved organic carbon from upland peat, Hydrol. Process., 16, 3487-3504, doi:10.1002/hyp.1111, 2002.

Worrall, F., Reed, M., Warburton, J., and Burt, T.: Carbon budget for a British upland peat catchment, Sci. Total Environ., 312, 133146, doi:10.1016/S0048-9697(03)00226-2, 2003.

Worrall, F., Burt, T., and Adamson, J.: Can climate change explain increases in DOC flux from upland peat catchments?, Sci. Total Environ., 326, 95-112, doi::10.1016/j.scitotenv.2003.11.022, 2004. 